\title{
Learning Styles, Personality Types and Reading Comprehension Performance
}

\author{
Nabiollah Sadeghi (Corresponding author) \\ Department of English, Faculty of Modern Languages and Communication \\ University Putra Malaysia (UPM), 43400 UPM Serdang, Selangor, Malaysia
}

Tel: 011-1550-4521Ｅ-mail: sadeghinabi@gmail.com

Zalina Mohd Kasim

Department of English, Faculty of Modern Languages and Communication

University Putra Malaysia (UPM), Malaysia

E-mail: zalina@fbmk.upm.edu.my

Bee Hoon Tan

Department of English, Faculty of Modern Languages and Communication

University Putra Malaysia (UPM), Malaysia

E-mail: tanbh@fbmk.upm.edu.my

Faiz Sathi Abdullah

Department of English, Faculty of Modern Languages and Communication

University Putra Malaysia (UPM), Malaysia

E-mail: mfaiz@fbmk.upm.edu.my

Received: December 6, 2011

Accepted: February 12, 2012

Published: April 1, 2012

doi:10.5539/elt.v5n4p116

URL: http://dx.doi.org/10.5539/elt.v5n4p116

\begin{abstract}
This study aims at reviewing the relationship between learning styles, personality and reading comprehension performance. In the last two decades, ample studies have been done to examine the relationship between learning styles, learner's personality and performance in academic settings. The reviewed studies substantiate that there is a relationship between personality types and/or traits of the learners, the way they establish their learning styles and their academic success in school and university both at an undergraduate and postgraduate level. Therefore, learners depending on the type of their personality resort to different learning styles or preferences which-in turn- affect their learning performance. However, there are no studies - either theoretical or empirical - examining exclusively the role of personality and learning styles on reading comprehension performance.

Moreover, the findings with regard to the bulk of research on the relationship between personality and success in reading comprehension- are not that congruent. Accordingly - due to the scarcity of the research on showing the relationship between personality, learning styles and achievement in reading comprehension, and also incongruity of the research results on personality and reading comprehension performance - the current study proposes that further research on the above areas would be of the great need.
\end{abstract}

Keywords: Learning styles and strategies, Personality traits/types, Reading comprehension

\section{Introduction}

Today, one of the dominant objectives in foreign language learning settings is to raise awareness about students' personal differences and their potential effects on the learning process and subsequently, on learning outcomes. Further, because of the numerous learner variables that appear to impinge on the process of language learning (Blair, 1982), the emphasis on the individual differences among learners is indeed pertinent in modern language teaching 
and its associated learning environments. The success of second language learning is due not only to cognitive factors but also to affective, motivational, personality, and demographic factors of the learners (Brown, 2000; Carrel et al, 1996), among which personality is of great importance (Carrell et al, 1996). Ackerman and Heggestad (1997) have suggested that individual difference variables such as personality, intelligence, and vocational interests can be used to explain not only variance in academic performance, but also the processes by which traits influence examination outcomes.

Accordingly, Ackerman's (1996) PPKI theory (intelligence as processes, personality, knowledge, and interests) tries to draw a conceptual framework for understanding the relation between non-cognitive and cognitive individual differences. The theory claims that personality traits play an important role in the development of knowledge in that they direct an individual's choice and level of persistence to engage in intellectually stimulating activities and settings.

Thus, it can be inferred from the PPKI theory that individual differences in personality may influence academic performance. Other studies have also shown that "non-intellectual" factors such as personality traits and learning styles are significantly involved in academic performance (Busato et al., 2000; Chamorro-Premuzic \& Furnham, 2003; De Fruyt \& Mervielde, 1996). This paper, through a review of related studies on the relationship between learning styles, personality and language learning performance, aims to shed more light on the relationship between personality, manifest as an affective learning style, and reading comprehension to draw attention to the need for further research that will help address the question: What is the role of personality in learning styles and reading comprehension? To date the available literature hardly reveals any significant research in this area.

\section{Interface between Learning Styles and Personality}

To understand better the relationship and/or connection between personality and learning styles, it would first be necessary to define these terms with regard to the current literature.

\subsection{Language Learning Styles}

Language learning styles and strategies are among the main factors that help determine how -and how well -our students learn a second or foreign language (Oxford, 2003). Oxford (2003) also asserts that learning styles are the general approaches - for example, global or analytic, auditory or visual - that students use in acquiring a new language or in learning any other subject. Cornett $(1983$, p.9) defines these styles as "the overall patterns that give general direction to learning behavior".

To further understand the importance of noticing learning styles in learning behavior, Felder and Henriques (1995) state that "Students learn in many ways, by seeing and hearing; reflecting and acting; reasoning logically and intuitively; memorising and visualising" (p.21). As the above statement shows, Felder and Henriques (1995) point to different groups of learning styles. These groups can also be considered as patterns that describe language learning behavior. To provide an overall picture of learning styles, Reid (1995) presents a comprehensive and categorical framework of learning styles; they (learning styles) have been divided into three major categories: cognitive learning styles, sensory learning styles, and personality learning styles.

Be that as it may, cognitive learning styles include: Field-independent vs. Field-dependent; Analytic vs. Global; and Reflective vs. Impulsive. Sensory learning styles may be divided into two other sub-categories: a) perceptual learning styles: Auditory learner, Visual learner, Tactile learner, Kinesthetic learner, and Haptic learner; b) Environmental learning styles: Physical vs. Sociological learner. Personality learning styles comprise: Extroversion vs. Introversion; Sensing vs. Perception; Thinking vs. Feeling; Judging vs. Perceiving; Ambiguity-tolerant vs. Ambiguity-intolerant; and Left-brained vs. Right-brained learners. However, it is behind the scope of this study to define all the above learning style categories and their classifications (see Chamot, 2005 for recent classifications and related issues).

Simply put, learning styles are the general approaches to learning a particular item. Accordingly, no two learners can be considered the same because of different individual characteristics. Hence, learning styles are the mental processes and instrumental settings a student uses most effectively while learning (More, 1993) that not only affect the process of learning but also individual learners who, based on preferences for different learning styles, learn differently and distinctively.

\subsection{Personality - Types and/or Traits}

Before putting forward the argument about the roles of personality and personality types in language learning, it should be mentioned that the terms "types" and "traits" have been used interchangeably in this study. However, the terms types and trait are simply different concepts from psychological and theoretical points of view; they originated in type and trait theories respectively. Personality type theory refers to the psychological classification of different 
types of people and it is distinguished from personality traits, which come in different levels or degrees. For example, according to type theories, there are two types of people, introverts and extroverts, but, according to trait theory, introversion and extraversion are part of a continuous dimension, with many people in the middle. However, the personality typology has some aspects of a trait theory; it explains people's behavior in terms of opposite fixed characteristics as trait theory does. With regard to the above issue, De Raad (1996) posits that the difference between traits and types is not very clear.

Personality awareness, apart from its pedagogical implications and importance, has already been a subject of curiosity and interest among individuals. There are three reasons for being interested in personality. They are; "first, to gain scientific understanding, second, to access people and next, to change people" (Cook, 1993, p. 3). For Cook (1993), the first reason seems theoretical while the second and the third ones are practical.

Richards and Schmidt (2002) define personality as "those aspects of an individual's behavior, attitude, beliefs, thoughts, actions and feelings which are seen as typical and distinctive of that person and recognized as such by that person and others" (p. 275). Based on this definition, each person has a type of personality which is exclusive to $\mathrm{him} /$ her. Another, perhaps a more comprehensible definition of personality is that personality is a stable set of characteristics and tendencies that determine those common abilities and differences in the psychological behavior (thoughts, feelings and actions) of people that have continuity in time and that may not be easily understood as the sole result of the social and biological pressures of the moment (Berens, 1999). It is clear that Berens (1999) in her definition of personality has insisted on two factors: stability and continuity of personality types.

Ehrman and Oxford (1990) posed nine major dimensions of learning styles among which personality types are one of those dimensions most strongly associated with L2 learning. They stated that personality types consist of four strands: extroverted vs. introverted; intuitive-random vs. sensing-sequential; thinking vs. feeling; and closure-oriented/judging vs. open/perceiving. Personality type (also called psychological type) is a construct based on the work of a Swiss psychiatrist, Carl Jung, who wrote the book Psychological Types in the 1920s. Later on, based on Jung's theory of personality type, a personality model named Myers-Briggs Type Indicator (MBTI) turned out and which is currently being used besides other personality models, e.g. Five Factor Model, Eysenck's model of personality, as a measuring instrument in many psychologically related studies.

To sum up, personality can be defined as a dynamic and organized set of characteristics possessed by every person that distinctively and uniquely influences his or her behaviors, motivations, and cognitions in various situations.

\subsection{Personality and Learning Styles}

Learning styles are not dichotomous (black or white, present or absent). Learning styles generally operate on a continuum or on multiple, intersecting continua. For example, a person might be more extraverted than introverted, or more closure-oriented than open, or equally visual and auditory but with lesser kinesthetic and tactile involvement. Few if any people could be classified as having all or nothing in any of these categories(Ehrman, 1996).Therefore, it can be noted that personality traits and learning styles are interwoven and operate on a continuum so that personality forms an important dimension of learning styles.

To understand better the interwoven relation between personality traits and learning styles, Brown (cited in Cohen, 1996)argues that learning strategies do not operate by themselves, but rather are directly tied to the learner's underlying learning styles (i.e., general approaches to learning) and other personality-related variables (such as anxiety and self-concept) in the learner. Furthermore, Schmeck (1988) exhorts researchers to view learning styles and learning strategies in the context of general personality factors such as the following: introversion and extroversion, reflectiveness and impulsiveness, field independence and field dependence, self-confidence and self-concept, self-efficacy and creativity, anxiety, and motivation (intrinsic and extrinsic).

According to Schmeck (1988), a learning strategy [Learning style]dis-embedded from personality-related factors is only a short-term prop for learning. Ehrman (2003) indicates to the fact that in the recent years the influence of personality variables on learning styles has increased greatly. Every individual uses a series of learning strategies and styles that are grounded in his/her personality to handle linguistic tasks and better to say language learning performance. Likewise, researchers make use of learning style research with personality and cognitive styles to determine ability, predict performance, e.g. in speaking or reading comprehension, and improve classroom teaching and learning (Reiff, 1992; Ehrman, 2001; Ehrman \& Oxford, 1995).

Additionally, different models of personality, e.g. the Five Factor Personality Model (Busato, et al., 1999, Chamorro-Premuzic et.al., 2003), temperament theory (Thomasand Chess, 1977), and the Myers-Briggs Type Indicator (MBTI) (e.g., Ehrman,1996; Leaver, 1998; Myers et al., 1998), Eysenck's model of personality(Erton, 2010) have been used by the researchers. All these models, as measuring instruments, help the researchers change 
personality as an abstract concept to a measurable scale ; therefore, they can investigate its relationship and effect on language learning related issues or in any other related fields of study.

Knowing that learning styles and strategies of individual students work together and the learner consciously chooses strategies that fit his or her learning style (Oxford,2003), it is clear that learning styles and personality traits operate together so that one cannot discuss about learning styles while ignoring personality traits of language learners as an abstract but affective variable. To put it simply, personality traits are expressed in learning styles, that learning styles are reflected in learning strategies, and that learning strategies are manifest in learning tactics, which in turn produce a likely outcome (Schmeck), cited in De Raad (1996). Accordingly, it seems logical to think of a mediational role for learning styles and strategies and an influencing role for personality traits in learning outcomes.

\section{Personality, Learning Performance and Styles}

The role of personality traits in learning process has been confirmed in the studies done during the last two decades. Since 1990s, there has been an increasing interest on showing how personality affects or, better to say, correlates with the academic performance. Personality type affects the way people respond to stimuli and the way that they prefer to learn (Carrel\& Monroe, 1993; Ehrman \& Oxford, 1990; Myers \& Myers, 1993).

De Raad in a review of personality, learning and education (1996), indicates to the mediating and moderating roles of personality variables in learning process and states that non-cognitive personality factors may appear as moderators of the general process of learning, because they interact with-or moderate-successive stages of the information processing sequence. Also, Murray and Mount, (1996) posit that an individual's personality can have an effect on to what extent he is able to achieve information. Accordingly, Blicke (1996) in a study analyzed the relation between personality traits, learning strategies, and performance among college students from different fields of study.

The results showed the relation between basic personality traits of the students (Openness to Experience and Conscientiousness), and their grades mediated by the learning strategies in the way that personality traits had an affective role in choosing appropriate learning strategies by the students and the learning strategies enhanced students' performance. In line with previous findings, Robinson et al, (1994) in the article entitled "Personality and second language learning" conclude that students with personality differences performed differently on oral and written measures of language learning. Also, Chamorro-Premuzic and Fumham (2003) conducted another study to understand the relationship between personality traits and academic performance in three longitudinal studies of two British university samples. Additionally, indicators such as attendance, tutorials, etc were also studied in relation with the personality traits in the above research. The results showed that personality is significantly related to the academic performance. Furthermore, Noftle and Robins (2007), in an analysis on the effect of personality on academic outcomes replicated the previous research results and maintained that personality traits "have independent and incremental effects on academic outcomes" (p. 116). The study (Noftle \& Robins, 2007 ) showed study, Conscientiousness, among other dimensions in the five factor model of personality, stood out as the strongest predictor of the students' college grades.

Therefore, Learners depending on the type of their personality resort to different learning styles which affect their learning performance. Similarly, Erton (2010) established the relationship between personality (extroversion-introversion) and foreign language learning. Again, the research, in accordance with the previous studies, e.g. Blick (1996); Noftle and Robins (2007), maintained that the reflections of different personality types could be observed in students' developing appropriate learning styles for themselves. Conclusively, the message of the above statements and studies is: style, among other things, can be seen as a conceptual bridge between cognition and personality which implies that styles can act as mediators and/or moderators on performance (Messick, 1994). In addition, personality traits/types as being expressed in styles (learning styles) can be viewed as non-cognitive psychological variables in learning performance.

In fact, studies have implied that learning styles may have mediator/moderator effects between personality and learning achievements (Blickle, 1996; Diseth, 2003).Thus, in achieving the academic goals and learning performance, personality is a dominant factor on the base of which students' learning styles shape and learning performance evolves. Moreover, personality variables, (affective learning styles) as moderators in the process of learning, i.e. second language learning have a direct or indirect influence on learners' performance.

\section{Personality and Reading Comprehension}

Reading comprehension is defined as the process of unlocking meaning from connected text. Up to now, reading comprehension as a great source of knowledge has been one of the important parts in second/foreign language tests and examinations; it plays a basic role in the educational and professional life of many students. The fact that each 
learner has his/her own performance in language skills induced Niaman (1978) and other researchers to focus on the concept "Good Language Learner" (GLL) to reveal learner characteristics contributing to successful language learning. Accordingly, and based on the fact that reading is integral to learning, it seems logical if someone thinks of the concepts "Good and Poor Readers" and the reasons why some readers outperform others as good readers?

The literature shows that personality is related to learning styles and learning is often contingent upon reading skills. Consequently, it is reasonable if someone presumes a relationship between personality and reading comprehension (Gray, 1999). On the other hand, most learners contribute their failure in reading tests to the complexity of reading comprehension text, while, some reasons root in affective variables among which personality is of the great importance. The fact that there is a relation between personality and reading comprehension has been verified in a few researches.

Millot and Cranney (1976) in a study on relationship between personality type and learning style in reading comprehension found a significant link between personality types of introversion, intuition and perceiving and learning style. Brown (1973) poses that maybe a relationship could be found between extraversion and reading comprehension. On contrary, Busch (1982) on a study using Eysenck Personality Inventory found a significant relationship between subjects' introversion personality type preference and their reading performance. Another study (Grey, 1999) was done on 400 college-bound students in the United States to detect possible reading comprehension skill problems in relation with affective learning style, determined by personality. The results showed a significant difference in the mastery level of seven out of thirteen reading comprehension skills, based upon personality type preferences, i.e. intuition and thinking. In the above study, MBTI personality model was used to determine the participant's type of personality.

Also, Pfister (2000) investigated the effect of personality type on English reading comprehension among college bilingual students in the United States; similar to the previous study, the researcher (pfister, 2000) employed MBTI model of personality as the research measuring instrument. The results demonstrated that students with EP (extroversion, perceiving) type got better scores on interpretive comprehension items while students with SF (sensing, feeling) type got better scores on literal comprehension items.

Generally, In Pfister's research extroverted students outperformed introverted ones in reading tests. To summarize, the dominant role of personality as an affective learning style on reading performance can be inferred from the above reviewed studies. However, the results are not as comprehensive and congruent as they are supposed to be, i.e. one cannot conclude which type(s) of personality contribute more to reading comprehension. In spite of this incongruity in research outcomes, no one can ignore the fact that predicting students' performance in reading comprehension and detecting their reading disabilities, dominant affective variables like personality should be taken into serious consideration alongside the other cognitive and non-cognitive variables. Therefore, more empirical studies to find more conclusive results in personality and reading comprehension research is still of the great need and interest.

\section{Discussion and Conclusion}

Current research on learning styles, personality types and L2 performance showed that there is a relationship between personality types of the learners, the way they establish their learning styles and their success in language learning. On the other hand, both theoretical and empirical studies showed the relationship and the effect of personality on reading comprehension. However, the results of empirical research in this area is not that congruent; different studies led to different incongruent findings.

Bailey, et al (2000) argued that this lazy situation may be the result of the indirect influence of personality factors on achievement since personality factors are precursors of attitudes toward the learning environment, which in turn affect the motivation of the learner. On the other hand, most of the studies in this area have been done in English speaking countries, e.g. the United States or places in which English has been considered as the second language.

Therefore, there is a need for future research to be done in non-English speaking countries as well to correlate the results in both settings. Also, the above reviewed studies on finding the relationship between personality and reading comprehension paid little, if not to say no, attention to the type of the text(s) as an effective variable in the process of reading comprehension. Sharp(2002) in a study to investigate the effect of text structure on reading comprehension, using cloze test procedure, found that among four text structures, i.e. problem-solution, listing, cause-effect, and description, the last one was significantly easier for all proficiency groups in both genders. Accordingly, it can be hypothesized that learners of the same personality type perform differently on different reading text types.

As a result, it is advisable if researchers interested in "reading-personality type studies" consider the type of the texts, 
e.g. expository, narrative, argumentative etc, beside other affective, cognitive and meta-cognitive variables. The literature of this study by touching on the reviewed studies (e.g. Robinson et al., 1994; Blickle, 1996, Boekaerts, 1996; Erton, 2010; Chamorro-Premizic, 2003; Ehrmanet al., 2003) showed that how learners based on different personality traits prefer their own learning styles for achieving a better performance in learning process.

In accordance with the above relation, i.e. personality, learning styles and learning performance, Gardner (2000) asserts that an interactional model is needed to understand fully the processes that are involved in second language learning. Specifically, he supports the use of an interactional model that includes measures of individual differences in motivation, aptitude, attitudes, and affective functioning, as well as the influences of various classroom and environmental factors. So, considering the above issues, it can be concluded that there is still a need for further empirical research to uncover more the relationship between learning styles, personality types and reading comprehension in order to come to a clear understanding of the above relationship and eventually of learners' individual differences.

\section{Implications for Teachers and Language Planners}

Successful school learning depends on many personal characteristics other than intelligence, such as persistence, interest in school, and willingness to study (De Raad et al., 1996). On the other hand, learners step into the learning process with their own predispositions, uniqueness and ways of learning a language including their own learning styles, strategies and personality types. They do not start this process with a so called "blank slate" in Chomsky's words. Therefore, in order to provide effective, sensitive instruction, teachers of L2 need to learn to identify and understand their students' significant individual differences (Carrell, 1996).

Personality, as one dimension of the learner individual characteristics, and also as an important psychological mechanism which guides behavior and leads to everyone having their own unique pattern of feelings, thoughts, and behaviors in the form of a fairly stable combination of personality traits (Phares, 1991) should be taken into consideration by both teachers and language planners. Teachers who teach reading comprehension should draw their attention on students' individual differences and uniqueness especially from personality types point of view.

Briefly put, traits (personality traits) never occur in any two individuals in exactly the same way (Allport, 1937), therefore, an awareness of these personality differences by both student and teacher is essential for the most efficient use of reading materials and methodologies presented in the classroom. Accordingly, Language planners beside language teachers need to touch on the learners' peculiarities, i.e. learning styles, personality, etc, to meet the various needs of the learners. In conclusion, I am convinced that the resulting understanding of the personality traits, learning styles and strategies that affect language learning skills and performance-among which reading comprehension is not an exception - is undoubtedly much broader.

\section{References}

Ackerman, P. (1996). Intelligence as process and knowledge: An integration for adult development and application. In W. Rogers, \& A. Fisk, et al. (Eds.), Aging and skilled performance: Advances in theory and application (pp. 139-156). Hillsdale, NJ: Erlbaum.

Ackerman, P., \& Heggestad, E. (1997). Intelligence, personality, and interests: Evidence for overlapping traits. Psychological Bulletin, 12, 219-245. http://dx.doi.org/10.1037/0033-2909.121.2.219

Allport, G. W. (1937). Personality: A Psychological Interpretation. Holt, Rinehart and Winston: New York.

Bailey, P., Onwuegbuzie, A. J., \& Daley, C. E. (2000). Using learning style to predict foreign language achievement at the college level. System, 28, 115-133. http://dx.doi.org/10.1016/S0346-251X (99)00064-0

Berens, L. V. (1999). Dynamics of personality type: Understanding and Applying Jung's Cognitive Processes. California: Telos Publications.

Blickle, G. (1996). Personality traits, learning strategies, and performance. European Journal of Personality, 10(5), 337-352.

Boekaerts, M. (1996). Personality and the psychology of learning. European. Journal of Personality, 10, 377-404.

Brown, H. D. (1991). Breaking the Language Barrier. Yarmouth, ME: International Press.

Brown, H. D. (2000). Principles of language learning and teaching. $4^{\text {th }}$ Ed. White Plains, NY: Longman.

Busato, V., Prins, F. J., Elshout, J. J., \& Hamaker, C. (1999). The relation between learning style, the Big Fivepersonality traits, and achievement motivation in higher education. Personality and Individual Differences, 26(1), 129-140.

Busato, V. V., Prins, F. J., Elshout, J. J., \& Hamaker, C. (2000). Intellectual ability, learning style, achievement 
motivation and academic success of psychology students in higher education. Personality and Individual Differences, 29, 1057-1068.

Blair, R. W. (1982). Innovative approaches language teaching. Rowley, MA: Newbury House.

Busch, D. (1982). Introversion-extroversion and the EFL proficiency of Japanese students. Language Learning, 46(1), 109-132.

Carrel, P. L., \& Monroe, L. B. (1993). Learning styles and composition. Modern Language Journal, 77(2), 148-162.

Carrel, P. L., Prince, M. S., \& Astica, G. G. (1996). Personality type and language learning in an EFL context. Language Learning Journal, 46, 75-99.

Chamorro-Premuzic, T., \& Fumham, A. (2003). Personality predicts academic performance: Evidence from two longitudinal university samples. Journal of Research in Personality, 37(4), 319. http://dx.doi.org/10.1016/S0092-6566(02)00578-0

Chamorro-Premuzic, T., Fumham, A., \& Lewis, M. (2007). Personality and approaches to learning predict preference fordifferent teaching methods. Learning and Individual Differences, 17(3), 241-250. http://dx.doi.org/10.1016/j.lindif.2006.12.001

Chamot, A. U. (2005). Language learning strategy instruction: Current issues and research. Annual Review of Applied Linguistics, 25(1), 112-130.

Cohen, A. D. (1996, July). Second language learning and use strategies: Clarifying the issues. Paper presented at the Symposium on Strategies of Language Learning and Use, Seville, Spain, December 13-16, 1994.

Cook, V. (1991). Second language learning and language teaching. London: Edward Amold.

Cook, V. (1993). Linguistics and second language acquisition. New York: St. Martin's Press.

De Raad, B., \& Schuwenburg, H. C. (1996). Personality in learning and education: A Review. European Journal of personality, 10, 303-306.

Cornett, C. E. (1983). What you should know about teaching and learning styles. Bloomington: Phi Delta Kappa Educational Foundation.

Diseth, A. (2001). Validation of a Norwegian version of the Approaches to Study Skills Inventory for Students (ASSIST): Application of structural equation modelling. Scandinavian Journal of Educational Research, 45(4), 381-394.

Diseth, Å. (2003). Personality and approaches to learning as predictors of academic achievement. European Journal of Personality, 17, 143-155. http://dx.doi.org/10.1002/per.469

Ehrman, M. E. (1996). Understanding Second Language Learning Difficulties. Sage, Thousand Oaks, CA.

Ehrman, M. E. (2001). Bringing learning strategies to the learner: the FSI language learning consultation service. In Alatis, J. E., Tan, A. (Eds.), Language in Our Time: Bilingual Education and Official English, Ebonics and Standard English, Immigration and the Unz Initiative. Georgetown University, Washington DC, pp. 41-58.

Ehrman, M. E., Leaver, B. L., \& Oxford, R. L. (2003). A brief overview of individual differences in second language learning. System, 31, 313-330.

Ehrman, M., \& Oxford, R. (1990). Adult language learning styles and strategies in an intensive training setting. Modern Language Journal, 74, 311-326.

Ehrman, M. E., \& Oxford, R. L. (1995). Cognition plus: Correlates of language learning success. Modern Language Journal, 79(1), 67-89.

Endler, N. (2000). The interface between personality and cognition. European Journal of Personality, 14, 377-389.

Erton, I. (2010). Relations between personality traits, language learning styles and success in foreign language achievement. Journal of Education, 38, 115-126.

Felder, M. Richard, \& Henriques, R. E. (1995). Learning and teaching styles in foreign and second language education. Foreign Language Annals, 28(1), 21-31.

Gardner, R. C. (2000). Correlation, causation, motivation, and second language acquisition. Canadian Psychology, $41,10-24$.

Leaver, B. L. (1998). Teaching the Whole Class (fifth ed). Kendall Hunt, Dubuque, IA.

Messick, S. (1994). The matter of style: manifestations of personality in cognition, learning, and teaching. 
Educational Psychologist, 29, 121-136.

Millot, R., \& Cranney, A. G. (1976). Personality correlates of college reading and study skills. Journal of Reading Behavior, 8(3), 335-336.

More, A., \& British Columbia Univ., V. (1993). Learning Styles and the Classroom. Retrieved from ERIC database.

Murray, R. B., \& Mount, M. K. (1996). Effects of impression management on self-deception on the predictive validity of personality constructs. Journal of Applied Psychology, 81(3), 261-272.

Myers, I. B., McCaulley, M. H., Quenk, N. L., \& Hammer, A. L. (1998). MBTI Manual: A Guide to the Development and Use of the Myers-Briggs Type Indicatorl, Third Edition. Consulting Psychologists, Palo Alto, CA.

Myers, I. B., \& Myers, P. B. (1993). Gifts Differing: Understanding Personality Type. Palo Alto, California: Consulting Psychologists Press.

Noftle, E. E., \& Robins, R. W. (2007). Personality predictors of academic outcomes: Big five correlates of GPA and SAT scores. Journal of Personality and Social Psychology, 93(1), 116-130. http://dx.doi.org/10.1037/0022-3514.93.1.116

Oxford, R. L. (2003). Language learning styles and strategies: An overview. Learning Styles and Strategies. Oxford, GALA. pp. 1-25.

Phares, E. J. (1991). Introduction to Psychology ( $3^{\text {rd }}$ ed.). New York: Harper Collins Publishers.

Reid, J. (1995). Learning styles in the ESL/EFL classroom. Boston, MA: Heinle and Heinle Publishers.

Reiff, J. (1992). Learning Styles: What research says to the teacher. National Education Assn, Washington, DC.

Robinson, D., Gabriel, N., \& Katchan, O. (1994). Personality and second language learning. Personality and Individual Differences, 16, 143-157.

Schmeck, R. (1988). Individual differences and learning strategies. In C. Weinstein, E. Goetz, \& P. Alexander (Eds.), Learning and Study Strategies. N. Y.: Academic Press. pp. 171-191.

Sharp, A. (2002). Chinese L1 school children reading in English: the effects of rhetorical patterns. Reading in a Foreign Language, 14(2), 111-135.

Shirley, C. L. (2007). Personality and second language learning in a defense program of modern standard Arabic studies. (Doctoral Dissertation). Palo Alto, CA: Consulting Psychologist Press Inc.

Thomas, A., \& Chess, S. (1977). Temperament and Development. Brunner/Mazel, New York. 